\title{
ZEASANTIN DARI MIKROALGA: BIOSINTESIS DAN PEMANFAATANNYA
}

\author{
Dispanstiani Abidin dan Ferry Karwur")
}

\begin{abstract}
ABSTRAK
Karotenoid merupakan pigmen alami yang disintesis oleh semua organisme fotosintetik, serta sejumlah bakteri dan jamur non-fotosintetik. Ada dua pengelompokan karotenoid alami: (1) karoten, seperti $\beta$-karoten dan $\alpha$-karoten, dan (2) santofil. Umumnya santofil seperti violasantin, antherasantin, zeasantin, neosantin, dan lutein diproduksi oleh tumbuhan tingkat tinggi, namun juga dapat disintesis oleh mikroalga hijau. Zeasantin merupakan salah satu pigmen yang berperan penting dalam pencegahan penyakit degenerasi makular akibat usia (AMD). Produksi zeasantin dapat dilakukan oleh beberapa mikroalga seperti Spirulina sp., Dunaliella salina, Chlamydomonas reinhardtii, Synechocystis, Microcystis aeruginosa, dan Porphyridium cruentum. Artikel ini akan membahas mengenai biosintesis zeasantin serta pemanfaatannya.
\end{abstract}

\section{ABSTRACT: Zeaxanthin from microalgae: Biosynthesis and its uses. By: Dispanstiani Abidin dan Ferry Karwur}

Carotenoids are natural pigments which are synthesized by all photosynthetic organisms and some nonphotosynthetic bacteria and fungi. There are two main classes of naturally occurring carotenoids: (1) carotenes such as $\beta$-carotene and $\alpha$-carotene and (2) xanthophylls. All xanthophylls such as violaxanthin, antheraxanthin, zeaxanthin, neoxanthin, and lutein produced by higher plants,but they are also synthesized by green algae. Zeaxanthin is a natural pigment that has potential role in the prevention of age-related macular degeneration (AMD). The zeaxanthin are produced by several microalgae, i.e. Spirulina sp., Dunaliella salina, Chlamydomonas reinhardtii, Synechocystis, Microcystis aeruginosa and Porphyridium cruentum. This article highlights the biosynthesis pathway of zeaxanthin and its uses as nutraceuticals.

\section{KEYWORDS: $\quad$ biosynthetic, zeaxanthin, microalgae}

\section{PENDAHULUAN}

Karotenoid adalah poliena isoprenoid yang tersusun dari 8 unit isoprena $\mathrm{C}_{5}$ (Gross, 1987). Karotenoid dibagi menjadi dua kelompok yaitu karoten dengan rumus hidrokarbon $\mathrm{C}_{40} \mathrm{H}_{56}$ dan turunannya yaitu santofil. Santofil meliputi violasantin, antherasantin, zeasantin, neosantin, dan lutein (Gross, 1991). Hampir semua organisme fotosintetik seperti tumbuhan, alga, dan bakteri fotosintetik mengakumulasikan karotenoid pada periperal antena yang terletak pada membran fotosintetik. Pada antena, karotenoid berfungsi sebagai light harvester untuk menyerap cahaya yang kemudian digunakan sebagai bahan bakar pada mesin fotosintesis. Fungsi karotenoid sebagai photo-protection (fotoprotektor) bertujuan menghindari terbentuknya singlet-oxygen yang sangat berbahaya. Dari segi manfaat, karotenoid pada manusia memberikan perlindungan sel dari efek karsinogenesis radikal bebas seperti kanker dan penyakit jantung. Kajian ilmiah ini bertujuan mengetahui biosintesis pigmen zeasantin serta pemanfaatannya sehingga dapat diketahui fungsi zeasantin lebih luas. Artikel ini akan membahas mengenai: jalur biosintesis, sumber zeasantin dari mikroalga, serta pemanfaatan zeasantin.

Nama lain zeasantin adalah ( $\left.3 R, 3^{\prime} R\right)-\beta, \beta$-karoten3,3'-diol. Zeasantin memiliki formula $\mathrm{C}_{40} \mathrm{H}_{56} \mathrm{O}_{2}$, berwarna oranye dan kuning (Nelis and DeLeenheer 1991; Handelman et al., 1999; Humphries \& Khachik, 2003). Zeasantin tidak menunjukkan aktivitas vitamin A. Zeasantin dan lutein memiliki hubungan dekat yang memegang peranan penting dalam pencegahan penyakit degenerasi makular akibat usia (AMD), serta penyebab kebutaan (Hadden et al., 1999).

Zeasantin merupakan molekul seperti poliena yang memiliki 9 ikatan karbon tunggal dan rangkap terkonjugasi. Ketika dieksitasi dengan cahaya monokromatik menunjukkan karakteristik panjang gelombang yang elastis dengan hamburan cahaya balik, disebabkan oleh vibrasi dalam struktur kimianya. Dua karakteristik puncak karotenoid menunjukkan adanya gerakan vibrasi molekul pada ikatan tunggal karbon $1159 \mathrm{~cm}^{-1}$ dan ikatan rangkap karbon dengan vibrasi $1525 \mathrm{~cm}^{-1}$ (Bhosale et al., 2003). Afinitas absorpsi ditentukan oleh panjang kromofor dan polaritas dari gugus fungsionalnya. Semua isomer

) Program Pascasarjana Magister Biologi, Universitas Kristen Satya Wacana, Salatiga 


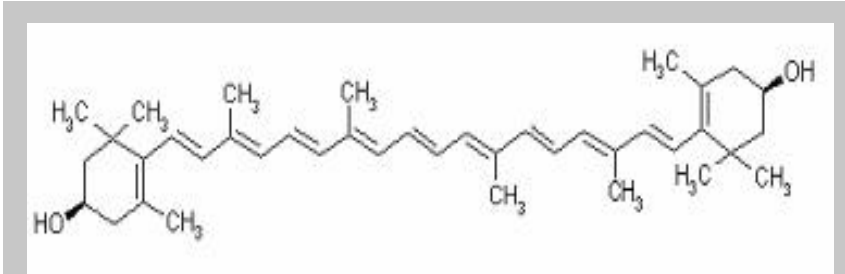

Gambar 1. Struktur kimia zeasantin (Britton, 1995).

trans memiliki serapan yang kuat pada panjang gelombang 400-500 nm, sedangkan isomer cis menunjukkan serapan pada wilayah UV, sekitar 320 $\mathrm{nm}$ (Rodriguez-Amaya, 2001). Spektrum tampak dari zeasantin menyerupai $\beta$-karoten.Serapan sinar ultraviolet dan sinar tampak zeasantin dapat dilihat pada Tabel 1 dan Gambar 2.

\section{JALUR BIOSINTESIS}

Biosintesis karotenoid berawal dari farnesil piropospat (FPP), yang berasal dari dua prekursor, isopentenil piropospat (IPP) dan dimetilalil piropospat (DMAPP). Secara umum, ada dua jalur untuk mensintesis IPP dan DMAPP yaitu mevalonate (dimulai dengan asetil KoA) dan non-mevalonate (dimulai dengan piruvat dan glyceraldehyde-3-pospat). Biosintesis karotenoid pada mikroalga menggunakan jalur non-mevalonate (Yuan et al., 2006). Prekursor isoprena dari karotenoid dan semua terpenoid adalah isopentenil piropospat (IPP). IPP diisomerisasi menjadi DMAPP, lalu DMAPP berikatan dengan IPP membentuk C10 geranil piropospat (GPP). GPP bergabung dengan 2 molekul IPP membentuk C15 FPP, FPP bergabung lagi dengan IPP membentuk C20 geranilgeranil piropospat (GGPP). GGPP digunakan untuk membentuk diterpen, seperti karotenoid (Gross, 1991).

Tabel 1. Serapan sinar ultraviolet dan sinar tampak dari zeasantin

\begin{tabular}{llc}
\hline Karotenoid & \multicolumn{1}{c}{ Pelarut } & \multicolumn{1}{c}{$\boldsymbol{\lambda}$ max nma } \\
\hline \multirow{4}{*}{ Zeasantin } & Aseton & $(430) 452479$ \\
& Kloroform & $(433) 462493$ \\
& Etanol & $(428) 450478$ \\
& Petroleum eter & (424) 449476 \\
\hline
\end{tabular}

a tanda kurung menunjukkan bahu, Sumber : Britton, 1995

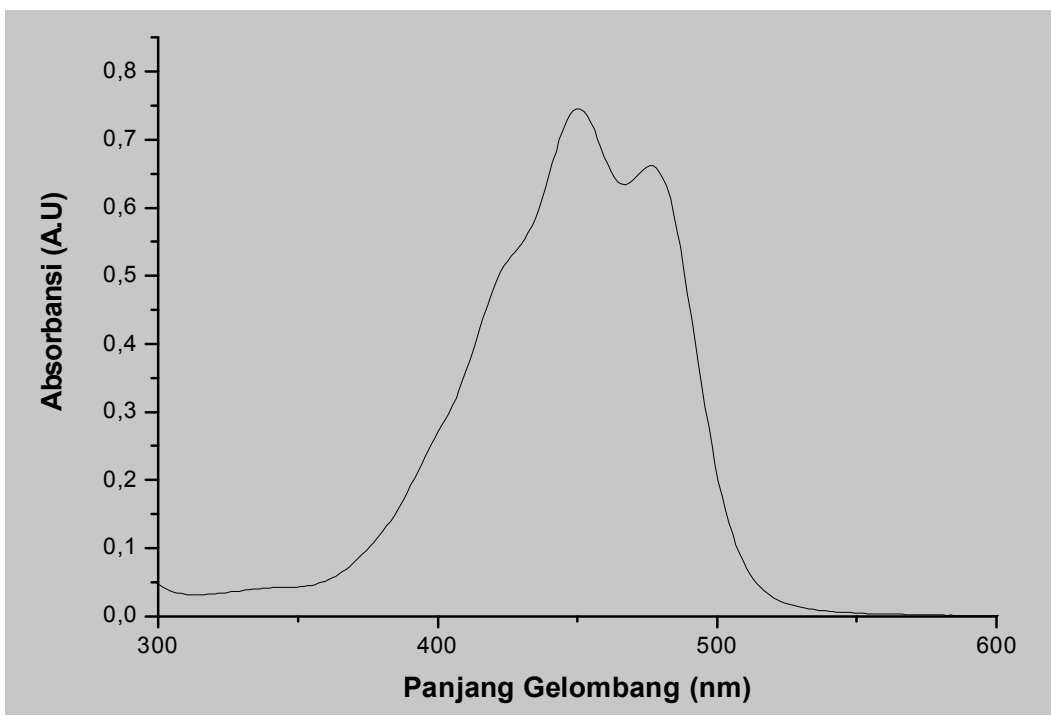

Gambar 2. Pola spektra zeasantin, pelarut aseton (Davies, 1976; Britton, 1995). 
Tahap unik pertama pada biosintesis karotenoid adalah kondensasi 2 molekul GGPP menjadi fitoen. Senyawa ini dibentuk oleh C40 siklopropana intermediet, prefitoen piropospat (PPPP) (Altman et al., 1972). Dari fitoen, likopen dapat dibentuk dengan cara dehidrogenasi. Pada tiap tahap proses dehidrogenasi, kromofor diperpanjang oleh 2 ikatan rangkap secara bergantian dari salah satu sisinya. Siklisasi juga terjadi pada karoten yang memiliki minimal ikatan rangkap pada C-7 dan 8. Pemasukan gugus fungsi oksigen, hidroksi, dan epoksi terjadi setelah proses siklisasi yang merupakan tahap akhir dari biosintesis ketika karoten dioksidasi. Perbedaanperbedaan dalam hal reaksi siklisasi, dehidrogenasi, dan oksidasi menyebabkan perbedaan-perbedaan dalam jenis karotenoid yang dihasilkan (Gambar 3). Enzim yang terlibat dalam jalur biosintesis ini adalah CrtE, CrtB, CrtL (likopen), CrtY ( $\beta$-karoten), dan CrtZ (zeasantin) (Yuan et al., 2006).

Beberapa penelitian biosintesis santofil dilakukan dengan alga dan bakteri. Pada tumbuhan tingkat rendah seperti halnya pada mikroalga, zeasantin dibentuk melalui hidroksilasi $\beta$-karoten. Karotenoid epoksi dapat dibentuk dari oksidasi karoten atau santofil. Sebagai contoh violasantin yang dibentuk dari epoksidasi zeasantin melalui antherasantin, yang merupakan suatu monoepoksi (Davies et al., 1970).
Pada mutasi alga hijau Chlamydomonas reinhardtii (Niyogi et al., 1997) ditemukan gen penyandi tunggal untuk enzim epoksidase zeasantin. Gen tunggal tersebut bertanggung jawab pada biosintesis yaitu dari violasantin selama pertumbuhan dan reaksi epoksidasi yang mendorong ke arah reaksi balik (reversible) dari zeasantin melalui antherasantin ke violasantin setelah adanya tekanan cahaya (Niyogi et al., 1997; Jin et al., 2003).

Pada mikroalga, kandungan zeasantin diregulasi oleh radiasi cahaya. Jika radiasi cahaya berlebihan pada fotosintesis maka akan mengakibatkan saturasi dalam kloroplas yang memicu terjadinya reaksi de-epoksidasi violasantin berbalik (reversible) ke bentuk antherasantin, dan selanjutnya mengakumulasi zeasantin dalam tilakoid kloroplas. Enzim yang mengkatalisis reaksi tersebut adalah violasantin de-epoksidase yang berada dalam lumen tilakoid kloroplas (Hager \& Holocher, 1994). Jika cahaya yang diserap lebih rendah dari yang diperlukan pada fotosintesis, zeasantin dikonversi kembali ke violasantin oleh enzim zeasantin epoksidase dengan monoepoksida antherasantin yang menjadi perantara dalam proses oksidasi-reduksi (Hager, 1980). Siklus santofil penting untuk perlindungan komponen fotosintesis dari fotooksidasi zeasantin, antherasantin

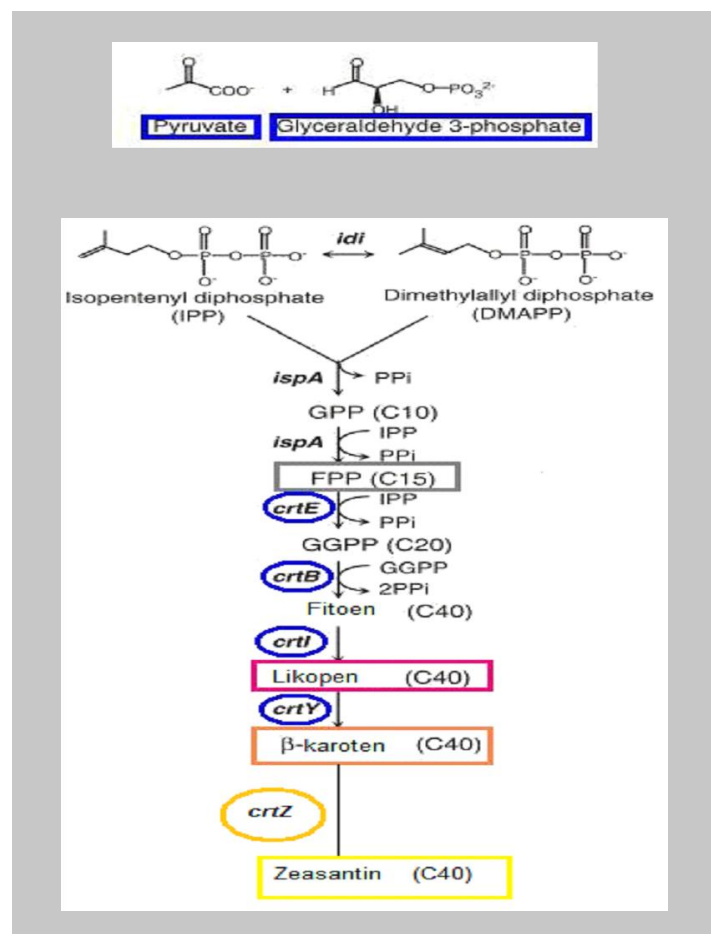

Gambar 3. Senyawa prekursor, karoten utama, santofil dan enzim yang terlibat pada jalur biosintesis karotenoid. DMAPP: dimetilallil piropospat; FPP : farnesil piropospat; GGPP : geranilgeranil piropospat; IPP : isopentenil piropospat; crtE dan crtB: tidak berwarna; crtL: likopen (merah muda); crtY: $\beta$-kaoten (oranye); crtZ: zeasantin (kuning) (Yuan et al., 2006). 
dan violasantin yang berhubungan dengan pemanen cahaya (Demmig-Adams \& Adams, 1992).

Zeasantin mampu menggantikan hilangnya epoksi karotenoid, antherasantin, violasantin, dan neosantin sebagai komponen kestabilan pemanenan cahaya (LHC II). Secara genetika, bakteri dan tumbuhan pada jalur biosintesis zeasantin, kantasantin, dan astasantin memberikan alternatif yang menarik dalam produksi secara in vivo (Misawa, 1995a, 1995b; Misawa \& Shimada, 1998). Sebagai contoh, alga biruhijau dapat direplikasi pada plasmidnya dengan gengen endogen oleh rekombinasi homolog (Lagarde et al., 2000). Synecocystis sp. strain PCC 6830 telah digunakan sebagai transformasi inang untuk memproduksi zeasantin in vivo.

\section{SUMBER ZEASANTIN DARI MIKROALGA}

\section{Dunaliella salina}

Beberapa mikroalga menghasilkan zeasantin (Ruther et al., 1997; Jin et al., 2003). Produksi zeasantin strain mutan zea1 dari Dunaliella salina dapat dipertimbangkan dalam eksploitasi komersial (Jin et al., 2001, 2003). Strain mutan ini memiliki kekurangan dalam tahap epoksidasi-zeasantin. Mutan zea1 kekurangan neosantin, violasantin, dan antherasantin tetapi mengakumulasi zeasantin dalam membran tilakoid di bawah kondisi pertumbuhan normal. Di bawah kondisi cahaya rendah, strain mutan memiliki kandungan zeasantin 15 kali lebih tinggi daripada tipe liar. Salah satu usaha untuk menghasilkan produksi zeasantin adalah menggunakan mesin metabolisme strain E.coli dengan menghasilkan zeasantin $1,6 \mathrm{mg} / \mathrm{g}$ dari berat kering (Albrecht et al., 1999; Jin et al., 2003).

\section{Synechocystis sp.}

Zeasantin pada Synechocystis sp. PCC6714 berada di luar membran. Pada percobaan untuk meningkatkan akumulasi zeasantin pada prokariotik fotoautotrofik Synechocystis sp. strain PCC 6803, digunakan gen-gen yang terlibat dalam sintesis karotenoid. Synechocystis sp. dapat meningkatkan akumulasi zeasantin pada strain mutan hingga 2,5 kali. Dengan menggunakan gen $p s b A l l$, organisme tersebut mengkode ekspresi protein D1 dari fotosistem II dan merupakan promotor yang kuat. Genom Synechocystis mengandung 3 gen pengkode protein D1 yaitu $p s b A l$, psbAll, dan psbAIII. Lokus psbAll dapat digunakan sebagai bentuk integrasi ekspresi gen pada Synechocystis sp. (Lagarde et al., 2000).

\section{Microcystis aeruginosa}

Mikroalga Microcystis aeruginosa dapat memproduksi zeasantin (Chen et al., 2005).

\section{Spirulina}

Spirulina biasa digunakan sebagai pakan alami dalam budidaya udang. Satu parameter penting dalam budidaya udang yaitu adanya peningkatan produksi zeasantin yang ditandai warna kulit karapaks. Zeasantin merupakan salah satu karotenoid utama pada Spirulina yang dengan cepat dikonversi menjadi astasantin (Liao et al., 1993). Spirulina juga meningkatkan pewarnaan kuning dan merah ayam petelur karena akumulasi zeasantin (Toyomizu et al., 2001).

\section{PEMANFAATAN ZEASANTIN}

Pemanfaatan karotenoid secara epidemiologi berhubungan dalam menurunkan resiko beberapa kanker dan AMD (Perez-Galves et al., 2003). Karotenoid dilaporkan penting sebagai faktor pelindung dalam epitelium retina pada bayi. Selain itu, penggunaan zeasantin dalam kosmetik, khususnya sebagai pelindung matahari, adalah sejalan dengan fungsi alami sebagai pelindung sel dari fotosensitisasi. Sejauh ini, pemanfaatan lain dari zeasantin yang dilaporkan adalah:

\section{Mencegah Age-related Macular Degeneration (AMD)}

AMD merupakan penyebab kebutaan pada orang dewasa karena adanya perubahan-perubahan yang terjadi pada pusat retina dan makula, yang akhirnya mendorong ke arah hilangnya kemampuan melihat. Lutein dan zeasantin berperan dalam pencegahan AMD. Zeasantin terakumulasi pada daerah makular retina manusia, di mana akan mencegah kerusakan oleh energi tinggi pada cahaya biru melalui karakteristik antioksidannya (Britton, 1995; Handelman et al., 1988; Snodderly, 1995).

\section{Menghambat Oksidasi LDL}

Karotenoid memegang peranan penting dalam menghambat makrofag dalam oksidasi LDL. Ketika zeasantin diinkubasi dengan makrofag-monosit manusia selama 24 jam dengan lipoprotein (LDL) rendah telah ditemukan dapat menghambat oksidasi LDL pada konsentrasi tertentu, sehingga zeasantin memperlambat terjadinya atherosklerosis (Keri et al., 1997). 


\section{Mencegah Kanker}

Zeasantin dapat mencegah kanker. Secara spontan karsinogenesis liver dalam $\mathrm{C} 3 \mathrm{H} / \mathrm{He}$ pada mencit jantan telah diuji ketika diberi makan $40 \mathrm{wk}$ zeasantin pada konsentrasi $0,005 \%$ dan dicampur sebagai emulsi dalam air minum (Nishino et al., 1999; Perez-Galves et al., 2003).

\section{Pigmentasi pada Ternak Unggas dan Ikan}

Zeasantin lebih banyak digunakan dalam meningkatkan pewarnaan pakan ternak dan ikan karena potensinya sebagai pewarna dan memiliki kemampuan dapat diserap dalam daging dan telur (Orndorff et al., 1994). Zeasantin 1,5 kali lebih kuat daripada lutein. Beberapa ikan dan krustasea, seperti udang dan ikan mas dapat mengubah zeasantin ke pigmen berwarna merah yaitu astasantin. Hal ini menunjukkan bahwa memberi makan pada ikan dan udang-udangan dari zeasantin tersebut dapat meningkatkan warna merah yang diinginkan (Gierhart, 1994).

\section{PENUTUP}

Zeasantin sangat berperan pada pencegahan AMD, menghambat oksidasi LDL, mencegah kanker dan pigmentasi pada ternak unggas dan ikan. Sumber zeasantin dapat ditemukan pada Spirulina sp., Dunaliella salina, Chlamydomonas reinhardtii, synechocystis, Microcystis aeruginosa, dan Porphyridium cruentum. Perlu adanya peningkatan pengelolaan pemanfaatan mikroalga sebagai salah satu sumber zeasantin.

\section{DAFTAR PUSTAKA}

Albrecht, M., Misawa, N., and Sandmann G. 1999. Metabolic engineering of the terpenoid biosynthetic pathway of Escherichia coli for production of the carotenoids $\beta$-carotene and zeaxanthin. Biotechnol. Lett. 21:791-5.

Bhosale, P., Ermakov, IV., Ermakova, M.R., Gellermann, W., and Bernstein, P.S. 2003. Resonant raman quantification of zeaxanthin production from Flavobacterium multivorum. Biotechnol. Lett. 25:1007-11.

Britton, G. 1995. Structure and properties of carotenoids in relation to function. FASEB. J. 9:1551-8.

Chen, F., Li , HB., Wong, RN., Ji, B., Jiang, Y. 2005. Isolation and purification of the bioactive carotenoid zeaxanthin from the microalga Microcystis aeruginosa by high-speed countercurrent chromatography. J. Chromatogr. A. 1064 (2):183-6.

Davies, B.H. 1976. Carotenoids. In: Goodwin TW, editor. Chemistry and Biochemistry of Plant Pigments. 2nd ed. London, U.K.: Academic Press. 38 pp.
Demmig-Adams, B., Adams, W.W. 1992. Photoprotection and other responses of plants to high light stress. Ann. Rev. Plant. Physiol. Plant. Mol. Biol. 43:599626.

Gierhart, D.L. 1994. Applied Food Biotechnology Inc., Production of Zeaxanthin and Zeaxanthin-Containing Compositions. U.S. patent 5,308,759.

Giraudat, J., Parcy, F., Bertauche, N., Gosti, F., Leung, J., Morris, P.C., Bouvier-Durand, M., and Vartanian, N. 1994. Current advances in abscisic acid action and signalling. Plant Mol Biol 26:1557-77.

Gross, J. 1987. Pigment in Fruits. Academic Press Inc. London.

Gross, J. 1991. Pigment in Vegetables: Chlorophylls and Carotenoids. Van Nostrand Reinhold, New York.

Hadden, W.L., Watkins, R.H., Levy, L.W., Regalado, E., Rivadeneira, D.M,, van Breemen RB., and Schwartz, S.J. 1999. Carotenoid composition of marigold (Tagetes erecta) flower extract used as nutritional supplement. J. Agric. Food. Chem. 47:4189-94.

Hager, A. 1980. The reversible, light-induced conversions of xanthophylls in the chloroplast. In: Czygan FC, editor. Pigments in Plants. Stuttgart: Fischer. p. 5779.

Hager, A. and Holocher, K. 1994. Localization of the xanthophyll-cycle enzyme violaxanthin deepoxidase within the thylakoid lumen and abolition of its mobility by a (light dependent) $\mathrm{pH}$ decrease. Planta 192:581-9

Handelman, G.J., Dratz, E.A., Reay, C.C., and Kuijk, FJGM. 1988. Carotenoids in human macula and whole retina. Invest. Opthalmol. Vis. Sci. 29:850-55.

Handelman, G.J,, Nightingale, Z.D., Lichtenstein, AH., Schaefer, E.J., and Blumberg, J.B. 1999. Lutein and zeaxanthin concentrations in plasma after dietary supplementation with egg yolk. Am. J. Clin. Nutr. 70:247-51.

Humphries, J.M. and Khachik, F. 2003. Distribution of lutein, zeaxanthin, and related geometrical isomers in fruit, vegetables, wheat, and pasta products. $J$. Agric. Food. Chem. 51: 1322-7.

Jin, E.S., Polle, JWE., and Melis, A. 2001. Involvement of zeasantin and of the Cbr protein in the repair of photosystem-Il from photoinhibition in the green alga Dunaliella salina. Biochim. Biophys. Acta. 1506:24459.

Jin, E.S., Feth, B., and Melis, A. 2003. A mutant of the green alga Dunaliella salina constitutively accumulates zeaxanthin under all growth conditions. Biotech. Bioeng. 81:115-24.

Jurgens, U.J. and Weckesser, J. 1985. Carotenoidcontaining outer membrane of Synechocystis sp. strain PCC6714. J. Bacteriol. 164(1):384-9.

Keri, L., Carpenter, H., Veen, C., Hird, R., Dennis, IF., Ding, T., and Mitchinson, MJ. 1997. The carotenoids â-carotene, canthaxanthin and zeasantin inhibit macrophage-mediated LDL oxidation. FEBS 18094 FEBS Lett 401:262-6.

Lagarde, D., Beuf, L., and Vermaas, W. 2000. Increased production of zeasantin and other pigments by 
application of genetic engineering techniques to Synechocystis sp. strain PCC 6803. Appl. Environ. Microbiol. 66:64-72.

Liao, W.L., Nur-E-Borhan, S.A., Okada, S., Matsui, T., and Yamaguchi, K. 1993. Pigmentation of cultured black tiger prawn by feeding with a Spirulina supplemented diet. Nippon Suisan Gakkaishi/Bull Japan Soc. Sci. Fisher. 59:165-9.

Misawa, N., Kajiwara, S., Kondo, K., Yokoyama, A., and Satomi, Y. 1995a. Canthaxanthin biosynthesis by the conversion of methylene to keto groups in a hydrocarbon carotene by a single gene. Biochem. Biophys. Res. Commun. 209:867-76.

Misawa, N., Satomi, Y., Kondo, K., Yokoyama, A., and Kajiwara, S. 1995b. Structure and functional analysis of a marine bacterial carotenoid biosynthesis gene cluster and astaxanthin biosynthetic pathway proposed at the gene level. J. Bacteriol. 177: 657584.

Misawa, N. and Shimada, H. 1998. Metabolic engineering for the production of carotenoids in noncarotenogenic bacteria and yeast. J. Biotechnol. 59:169-81.

Nelis, J.H. and DeLeenheer, P.A. 1991. Microbial sources of carotenoid pigments used in foods and feeds. $J$. Appl. Bacteriol. 70:181-91.

Nishino, H., Tokuda, H., Satomi, Y., Masuda, M., Bu, P., Onozuka, M., Yamaguchi, S., Okuda, Y., Takayasu, J., Tsuruta, J., Okuda, M., Ichiishi, E., Murakoshi, M., Kato, T., Misawa, N., Narisawa, T., Takasuka, N., and Yano, M. 1999. Cancer prevention by carotenoids. Pure Appl. Chem. 71(12):2273-8.

Niyogi, K.K., Bj “orkman, O., and Grossman, AR. 1997. Chlamydomonas xanthophyll cycle mutants identified by video imaging of chlorophyll fluorescence quenching. Plant Cell 9 :1369-80.
Orndorff, S.A., Campbell, EA., Medwid, R.D., and inventors; 1994. Zeasantin producing strains of Neospongiococcum excentricum. U.S. patent $5,360,730$.

Perez-Galvez, A., Martin, H.D., Sies, H., and Wilhelm, S. 2003. Incorporation of carotenoids from paprika oleoresin into human chylomicrons. Brit. J. Nutr. 89 (6):787-93.

Rodriguez-Amaya, D.B. 2001. General procedure and sources of errors in carotenoid analysis. In: A Guide to Carotenoid Analysis in Foods. Intl. Life Sciences Inst. ILSI Press. Washington, D.C. 23 pp.

Ruther, A., Misawa, N., Boger, P., and Sandmann, G. 1997. Production of zeasantin in Escherichia coli transformed with different carotenogenic plasmids. Appl. Microbiol. Biotechnol. 48:162-7.

Snodderly, D.M. 1995. Evidence for protection against age-related macular degeneration by carotenoids and antioxidant vitamins. Am. J. Clin. Nutr. 62 (Suppl):1448S-61S.

Toyomizu, M., Sato, K., Taroda, H., and Kato, T. Akiba Y. 2001. Effects of dietary of Spirulina on meat color muscle of broiler chickens. Br. Poult. Sci. 42:197202.

Walton, D.C. and Li, Y. 1995. Abscisic acid biosynthesis and metabolism. In: Davies PJ, editor. Plant Hormones. Dordrecht, the Netherlands: Kluwer Academic Publishers. p. 140-57.

Yuan, L.Z., Pierre, E., Rouvière, Robert , A., LaRossa, and Wonchul, Suh. 2006. Chromosomal promoter replacement of the isoprenoid pathway for enhancing carotenoid production in E. coli. Metabolic. Engineering 8: 79-90.

Zeevaart, J.A.D. and Creelman, RA. 1988. Metabolism and physiology of abscisic acid. Ann. Rev.Plant. Physiol. Plant. Mol. Biol. 39:439-73. 


\section{INFORMASIPUBLIKASI PERPUSTAKAAN \\ BALAI BESAR RISET PENGOLAHAN PRODUK DAN BIOTEKNOLOGI KELAUTAN DAN PERIKANAN}

\section{BUKU BARU}

1. Modified Atmospheric Processing and Packaging of Fish. : Filtered Smoke, Carbon Monox ide, e Reduced Oxygen Packaging. /Ed by W. Steven Otwell; Hordur G. Kristinsson; Murat O. Balaban. .- Lowa. : Blackwell Publishing,2006.

2. Marine Products for Healthcare : Fuctional and Bioactive Nutraceutical Compounds from the Ocean. Nazhiyil Venugopal .-Boca Raton. : CRC,2009.

3. Statistik. /Departemen Kelautan dan Perikanan. .- Jakarta. : Departemen Kelautan dan Perikanan,2007.

4. Prosiding Seminar Nasional Perikanan 2008 4-5 Desember 2008. /Pusat Penelitian dan Pengabdian Masyarakat. .- Jakarta. : Pusat Penelitian dan Pengabdian Masyarakat,2008.

5. Prosiding Workshop Nasional Riset Sosial Ekonomi Kelautan dan Perikanan. : Bogor, 2-3 Agustus 2006. /ed by Luky Adrianto; Agus Heri Purnomo; Sonny Koeshendrajana; Ary Wahyono; Asnawi. .- Jakarta. : Departemen Kelautan dan Perikanan,2008.

6. Prosiding Simposium Nasional Hasil Riset Kelautan dan Perikanan Tahun 2007. /Badan Riset Kelautan dan Perikanan. .- Jakarta. : Badan Riset Kelautan dan Perikanan,2007.

7. $\mathbf{1 0 0}$ Indonesia Inovations. /Kementrian Negara Riset dan Teknologi. .- Jakarta. : Kementrian Negara Riset dan Teknologi,2009.

8. Membuat 50 Jenis Bakso Sehat \& Enak. /Singgih Wibowo. .- Jakarta. : Penebar Swadaya,2009.

9. Indikator Kinerja Makro. : Pembangunan Kelautan dan Perikanan. /Departemen Kelautan dan Perikanan. .- Jakarta. : Departemen Kelautan dan Perikanan,2007.

10. Marine Biodiversity Review of the Arafura and Timor Seas. Ministry of Marine Affairs and Fisheries. .- Jakarta. : Ministry of Marine Affairs and Fisheries,2008.

11. Prosiding Seminar Nasional Tahunan V Hasil Penelitian Perikanan dan Kelautan Tahun 2008. : Jilid 1 Budidaya Perikanan. /Balai Besar Riset Pengolahan Produk dan Bioteknologi Kelautan dan Perikanan. .- Jakarta. : C,2008.

12. Prosiding Seminar Nasional Tahunan V Hasil Penelitian dan Perikanan Tahun 2008. : Jilid 2 Manajemen Sumberdaya Perikanan. /Balai Besar Riset Pengolahan Produk dan Bioteknologi Kelautan dan Perikanan. .- Jakarta. : Balai Besar Riset Pengolahan Produk dan Bioteknologi Kelautan dan Perikanan,2008.

13. Prosiding Seminar Nasional Tahunan V Hasil Penelitian Perikanan dan Kelautan Tahun 2008. : Jilid 3 Pasca Panen Hasil Perikanan dan Bioteknologi. /Balai Besar Riset Pengolahan Produk dan Bioteknologi Kelautan dan Perikanan. .- Jakarta. : Balai Besar Riset Pengolahan Produk dan Bioteknologi Kelautan dan Perikanan,2008.

14. Pengaruh Campuran Ekstrak Air Daun Sirih (Piper betir $L$ ) dan Ekstrak Air Beras (Oryza sativa $L$ ) terhadap Masa Simpan Ikan Kembung Banjar (Rastrellinger kanagurta Cuvier) Segar Pada Suhu Kamar. IKurnia Kusumawati. .-Jakarta. : Universitas Pancasila,2008.

15. Karakterisasi Pembentukan Gel Alginat Dari Rumput Laut Sargassung sp. Dan Turbinaria sp. /Subaryono. .-Bogor. : Institut Pertanian Bogor,2009.

16. Produksi Bubuk Flavour Enchancer Udang Dari Limbah Kepala Udang Windu (Penaeus monodon) Dengan Cara Hidrolisis Enzim Papain. /Lina Yulistianti. .—Jakarta. : Universitas Is lam Negeri Syarief Hidayatullah, 2009.

17. Teknologi Pengolahan Hasil Perikanan IHari Eko Irianto; Sri Giyatmi,._-jakarta :

Universitas Terbuka, 2009. 